\title{
ANIMASI DENGAN EFEK ILUSTRASI PENSIL (2D) PADA VIDEO KLIP MUSIK
}

\author{
Satrya Mahardhika'; ${ }^{1}$ Ardiyan $^{2}$; Ardiyansah $^{3}$ \\ 1, 2, 3 Jurusan Desain Komunikasi Visual, Fakultas Komunikasi dan Multimedia, \\ Bina Nusantara Universiy, Jln. K.H. Syahdan No. 9, Kemanggisan Jakarta Barat \\ satrya.mahardhika@gmail.com, iyan@binus.ac.id, sah@binus.ac.id
}

\begin{abstract}
This research is to explore various styles of animation in making video clip of a new band. Besides defining the exact visual style, the process is important to bring animation out of $2 D$-3D dichotomy. Doodle style is chosen as it suits particular theme of the band's songs and music genre. Meanwhile, the style defining is related to the efficiency and efforts to be out of mindset that animation is just about technique skill instead of about creativity.
\end{abstract}

Keywords: pencil illustration, sketch, doodle, visual effect, video clip

\begin{abstract}
ABSTRAK
Penelitian ini dimaksudkan untuk meng-eksplorasi berbagai gaya dalam animasi untuk keperluan pembuatan video klip sebuah band baru. Selain untuk mendapatkan visual style yang tepat, proses ini menjadi penting untuk membawa animasi keluar dalam dikotomi 2D-3D.Gaya coretan pensil (doodle) dipilih sebab sangat sesuai dengan tema yang diusung oleh lagu dan jenis musik band tersebut, selain itu pemilihan gaya ini sangat terkait dengan efisiensi dan upaya untuk keluar dari mindset bahwa animasi itu hanya soal adu teknik dari semestinya adu kreatifitas.
\end{abstract}

Kata kunci: ilustrasi pensil, sketsa, doodle, visual effect, video klip 


\section{PENDAHULUAN}

Berbicara tentang animasi, kita tidak hanya sekedar berbicara dalam lingkup teknis. Tetapi sebagaimana sebuah karya, animasi juga memiliki banyak gaya dan cara berkomunikasi secara visual. Tidak benar bahwa terdapat hirarki dalam visual style sebuah karya animasi, dimana terdapat kecenderungan persepsi bahwa animasi 3D selalu lebih "keren" daripada yang 2D, atau animasi 3D adalah sebuah tingkatan yang lebih tinggi daripada jenis animasi lainnya.Sehingga seolah-olah teknikteknik animasi sebelum era digital -terutama 3D (CGI)- adalah sesuatu yang buruk sehingga harus ditinggalkan.Parahnya, dikotomi 2D-3D dipahami secara fanatik oleh sebagian praktisi animasi, juga oleh mahasiswa dan pengajar bidang Animasi.

Animasi tentu tidak hanya sekedar urusan berapa dimensi.Visual style dalam animasi sangat beragam, berbanding lurus dengan perkembangan dunia seni rupa dan teknologi. Animasi klasik yang mengandalkan kemampuan gambar dan manual skill, animasi realis, animasi surealis, animasi organik, motion art, dan bermacam cara "bertutur" dalam animasi, adalah kekayaan yang semestinya membuat dunia animasi tidak selalu hanya dibatasi dalam konteks teknis yang sebenarnya kurang relevan. Penerapan sebuah gaya dalam animasi adalah pilihan tergantung solusi untuk menjawab kebutuhan tertentu. Meskipun benar bahwa perbendaharaan elemen visual saat ini sangat dipengaruhi oleh teknologi, tetapi tidak selalu animasi 3D dengan segala kecanggihannya mampu menjawab permasalahan yang disodorkan.Secara konseptual animasi, visual styledibutuhkan untuk mencapai kebutuhan tertentu yang memberikan nuansa pada audienceyang melihat sehingga tercipta keselarasan dari lagu, cerita, dan visual. Diantara berbagai macam gaya animasi yang memungkinkan dilakukan, penulis memilih untuk menerapkan animasi dengan gaya coretan tangan (doodle) dalam proyek video klip sebuah band baru. Hal ini terkait dengan style dan mood yang ingin dibangun dalam video klip ini, yaitu kesan romantik klasik yang disesuaikan dengan tema lagu yang dibawakan, tetapi bisa dilakukan dengan budget yang terbatas.

\section{METODE PENELITIAN}

Penelitian dilakukan dengan melakukan eksplorasi terhadap berbagai jenis dan gaya visual dalam animasi, mencari berbagai referensi terkait fitur tersebut baik berupa buku tercetak, file gambar maupun audio visual, serta didukung penerapan prinsip-prinsip desain untuk memperoleh perpaduan warna, bentuk, dan komposisi yang proporsional.

\section{PEMBAHASAN}

\section{Perkembangan Video Klip di Indonesia}

Beberapa tahun terakhir kualitas kreatif video klip di Indonesia tidak bisa dikatakan membaik.Hal ini terkait trend industri musik yang tidak lagi mengandalkan video klip sebagai media promosi.Terbatasnya kesempatan untuk ditayangkan di televisi dan minimnya apresiasi terhadap sebuah video klip akhirnya berdampak pada kualitas.Apalagi produk industri musik saat ini tidak harus dikemas dan dijual dalam format album yang terdiri atas kumpulan banyak lagu.Sebuah single sudah bisa menjadi komoditas dan bisa dipasarkan sebagai RBT (Ring Back Tone). Walaupun mengalami pergeseran fungsi, video klip tetap menjadi pilihan dalam rangka promosi sebuah karya musik.Meskipun hanya ditampilkan beberapa detik, sebuah video klip tetap wajib ada.Hal inilah yang menjadi tantangan bagi orang-orang kreatif yang terlibat dalam pembuatan video klip untuk mampu 
menampilkan video klip yang meskipun tidak memiliki budget yang berlebih, tetapi mampu memiliki daya tarik tersendiri.Oleh karena itulah, dalam menggarap sebuah video klip, saat ini dituntut efisien, praktis, ekonomis dan tetap kreatif.

Teknologi digital saat ini sangat mendukung kreatifitas. Tetapi kebanyakan video klip di Indonesia masih mengandalkan real shot yang diyakini memiliki cost lebih rendah dibandingkan harus menggunakan animasi atau visual efek. Hal inilah yang menjadi tantangan untuk menerapkan animasi dengan konsep coretan tangan (doodle) yang digabung dengan real shot sehingga membangun sebuah cerita yang mendukung lirik. Kekuatan visual itu sendiri mencerminkan karakter sebuah band dan lagu yang ingin mereka sampaikan. Dalam perjalanannya beberapa band mempunyai karakter yang cukup kuat dan membuat mereka dikenal dari hanya melihat video clip atau mendengar warna musik mereka. Disinilah kekuatan visual dibutuhkan untuk mempermudah musisi menghantarkan cerita lagu mereka dalam bentuk visual yang mampu membius para pemirsa.

\section{Requirement dan Visual Style}

Seperti banyak band di Indonesia, Legna adalah sebuah band baru dalam asuhan sebuah label tersohor yang mengusung tema asmara dalam lagu-lagunya.Meskipun klise, tetapi hingga hari ini tema semacam itulah yang masih menjadi komoditi utama industri musik di tanah air. Sebagai band yang mengusung genre sweet pop, Legna mengusung musik yang ringan, simpel, mudah dipahami, dan tidak terlalu berorientasi pada musikalitas seperti kebanyakan band rock. Lagunya yang berjudul "Ya ya ya" bercerita tentang hubungan asmara sepasang muda-mudi yang berakhir bahagia. Brief yang diterima, video klip harus di-treatment sebagai gabungan antara real shot dan animasi ikon-ikon hasil coretan tangan (doodle) yang mendukung dan atau menjelaskan gagasan dari lirik lagu tersebut.

Pendekatan doodle dipilih sebagai bentuk visualisasi yang ringan dan mudah diterima oleh para muda-mudi, serta untuk lebih menonjolkan pasangan yang terdapat dalam real shot tersebut. Sebagai pelengkap atau elemen visual pemilihan konsep doodle disini memberikan penambahan nilai estetika seperti visualisasi ruangan dan environmentuntuk menambahkan kesan 'meruang' dan mampu menghantarkan isi cerita kepada pemirsa dalam bentuk yang mudah dicerna. Selain itu ada beberapa tambahan requirement seperti scene dan environment yang digambar sebagai setting virtual adalah yang berkaitan dengan kota Paris yang diyakini sebagai kota paling romantis di dunia. Ikon asmara.

\section{SeputarDoodle}

Doodle biasa digunakan untuk menyebut coretan tangan yang dibuat secara asal-asalan sembari melamun atau sambil bercakap-cakap atau sambil memikirkan sesuatu. Meskipun tidak disengaja sebagai sebuah gambar yang serius, tetapi dari coretan tangan yang spontan tersebut seringkali berlanjut menjadi suatu ide atau karya yang punya kekuatan tersendiri.Coretan tangan manusia yang spontan, dipercaya sebagai bentuk ungkapan yang jujur dari perasaan seseorang.

Dari doodle inilah penulis mendapatkan ide untuk menjadikannya sebuah karya animasi. Digabungkan dengan video hasil shoot, selanjutnya coretan tangan hasil doodling digabungkan sehingga menjadi sebuah video klip yang mampu mengkomunikasikan pesan atau cerita yang ingin disampaikan oleh lirik lagu tersebut secara unik.

\section{Produksi Video Klip}

Produksi video klip ini secara garis besar terbagi dalam dua kelompok, yaitu pengambilan gambar (shooting) para personel band dan model sebagai tokoh utama dalam video klip ini. Serta proses pembuatan animasi doodle yang mendukung konsep storytelling video klip ini. 
Proses shooting dilakukan didalam ruangan putih (white limbou) yang nantinya digunakan sebagai canvas untuk menempatkan animasi dan visual efek. Pemilihan background putih ditentukan untuk mempermudah proses penempatan doodle tersebut, dengan warna putih penulis akan lebih mudah untuk memisahkan antara object dan background sehingga penempatan doodle menjadikan penambahan estetika dan menciptakan kedalaman ruang dalam sebuah shot. Adegan-adegan yang dishoot tentu saja mengikuti brief yang sebelumnya diberikan oleh director. Gambar 1 sampai 4 berikut adalah beberapa hasil capture video hasil shoot sebelum digabungkan dengan ilustrasi yang dianimasikan:

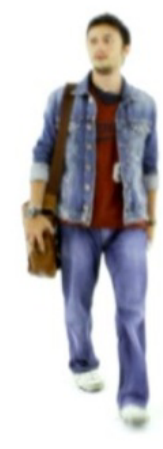

Gambar 1 Seolah-olah berada dalam sebuah café, selain satu set meja dan kursi yang tampak akan ditampilkan sebagai ilustrasi pensil (sketsa)

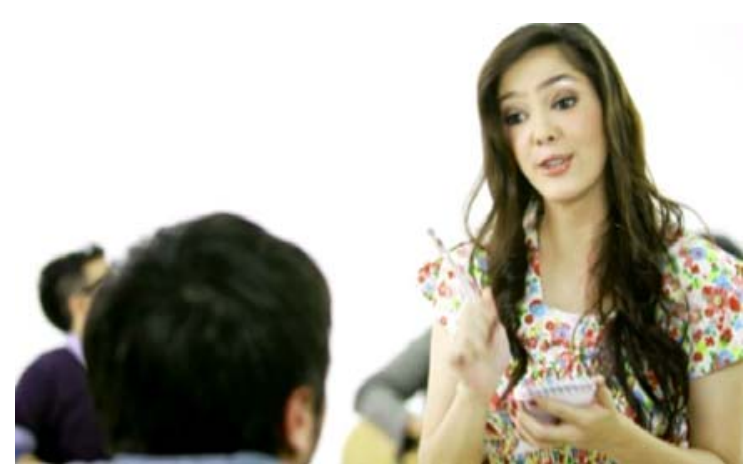

Gambar 2 Bagian yang kosong itu nantinya akan diisi oleh animasi elemen-elemen grafis yang dinamis

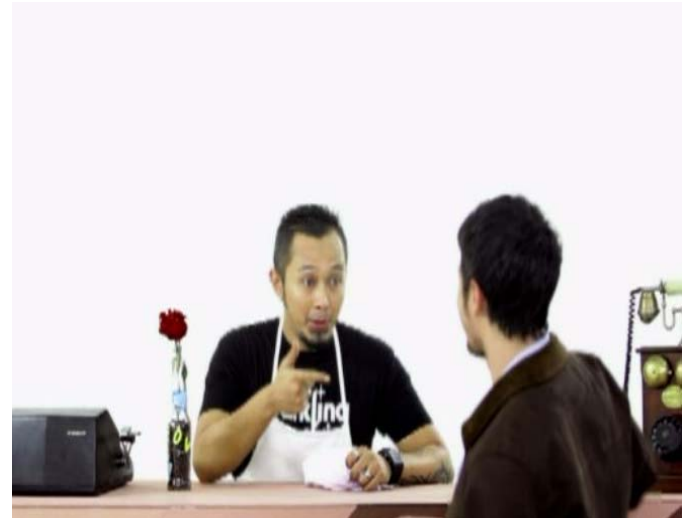

Gambar 3 Bagian yang kosong dibelakang barista itu nantinya akan diisi gambar-gambar untuk mendukung setting didalam sebuah café

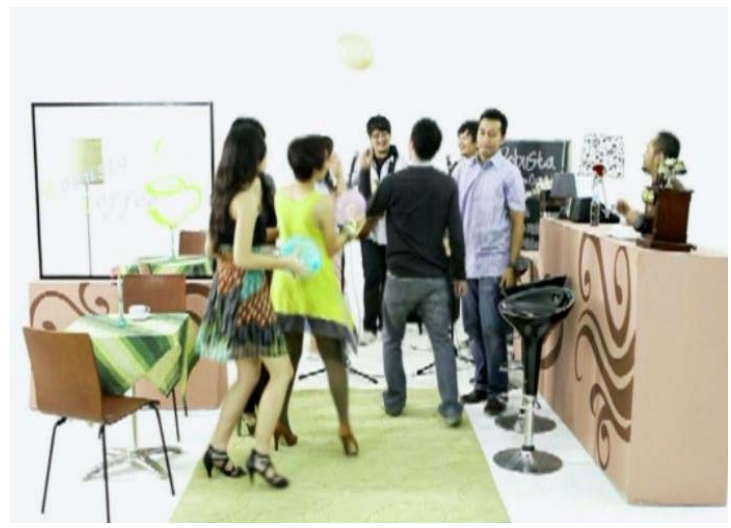

Gambar 4 Di scene ini juga akan dimainkan banyak elemen grafis dan ikon-ikon yang akan ditutup oleh logo band bersangkutan (Legna)

Di bagian animasi, persiapan dimulai dengan membuat gambar-gambar yang dibutuhkan secara manual. Seorang artis menggambar ikon, objek, elemen grafis, bahkan scene yang nantinya digunakan sebagai setting virtual para model yang sebelumnya sudah di-shoot tadi menurut creative brief yang diberikan. Beberapa gambar yang dibuat diantaranya terlihat pada Gambar 5 sampai 9 berikut ini. 


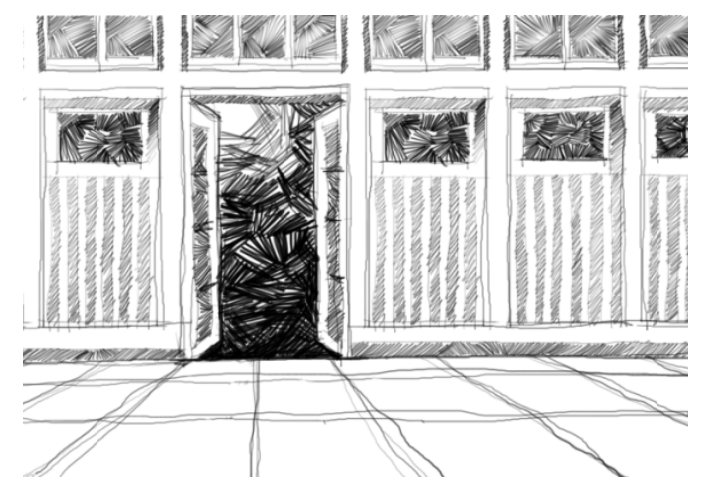

Gambar 5 Gambar Interior Café (tepat menghadap pintu)

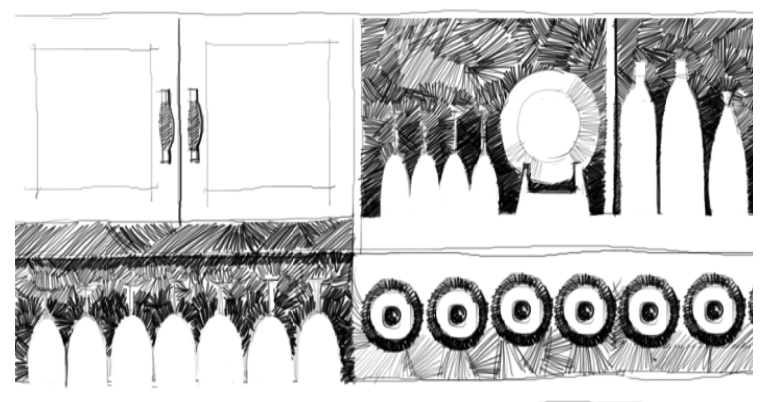

Gambar 7 Gambar Interior Café (Bar)

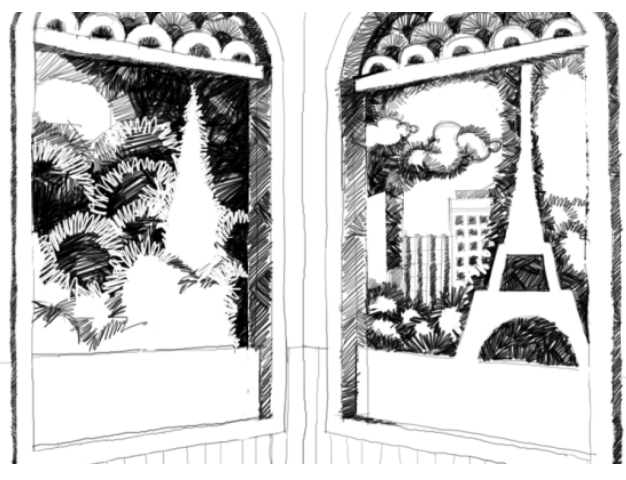

Gambar 6 Gambar Interior Café dengan latar belakang Menara Eifel

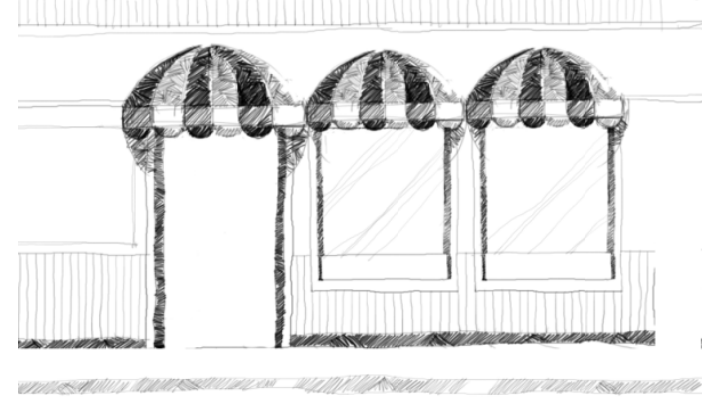

Gambar 8 Gambar Eksterior Café

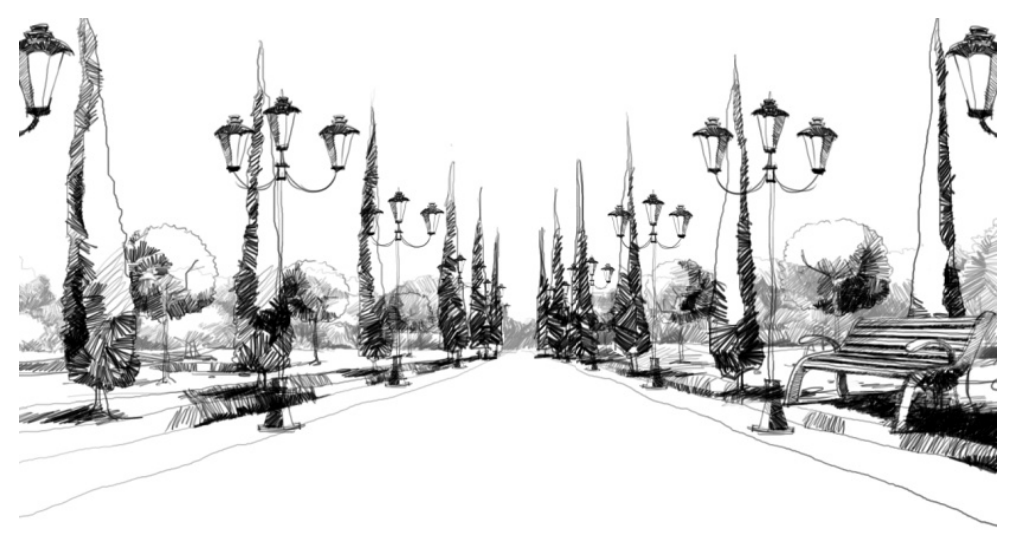

Gambar 9 Gambar Suasana Taman

Selain gambar-gambar yang nantinya berfungsi sebagai setting, yang harus disiapkan adalah gambar yang nantinya berfungsi sebagai ikon dan elemen grafis untuk memberikan efek dinamis dalam keseluruhan visual look video clip tersebut , diantaranya terlihat pada Gambar 10. 

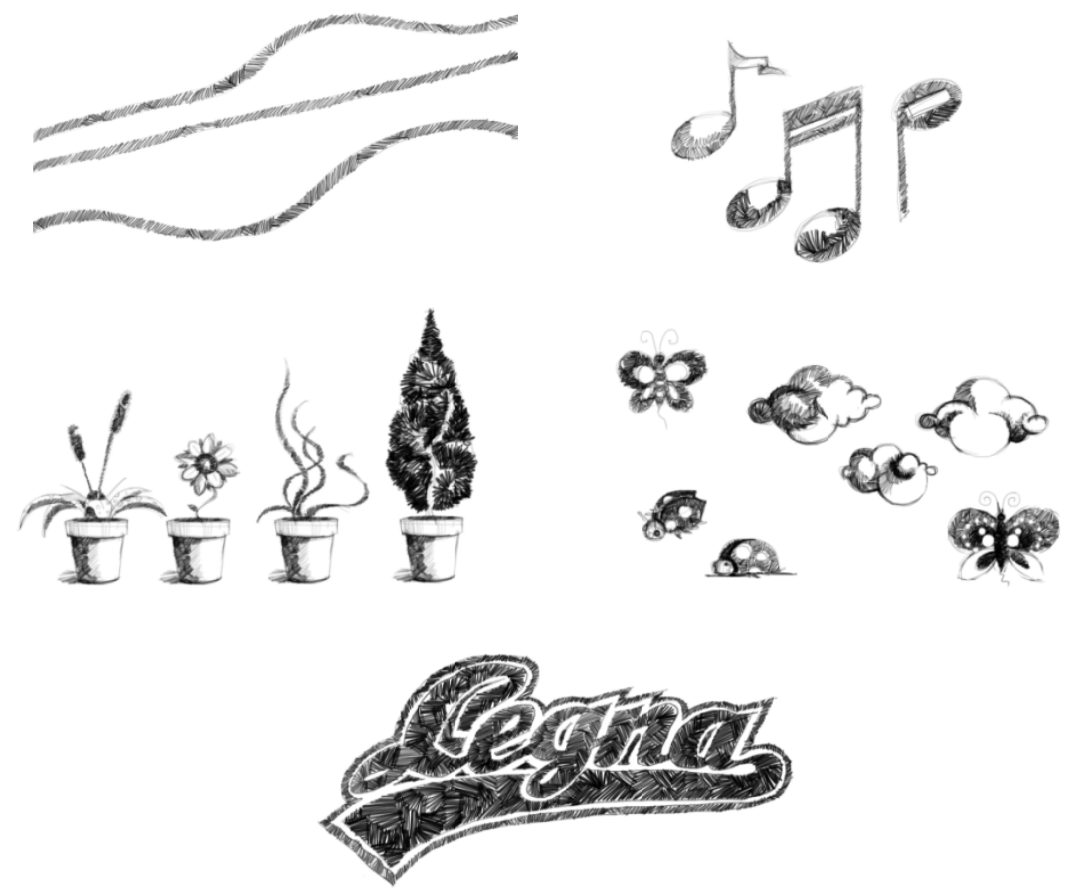

Gambar 10 Gambar-gambar untuk mendukung efek dinamis video clip.

Setelah gambar-gambar tersebut selesai dibuat, langkah selanjutnya adalah mulai menggabungkannya dengan video hasil shot yang sebelumnya sudah jadi. Proses ini menjadi vital karena disinilah antara animasi dan real shot di-compose secara apik sehingga menghasilkan sajian visual yang menarik. Goal dari video clip ini adalah memberikan ilusi gambar atau ruangan untuk memaparkan cerita dalam lagu band tersebut menjadi mudah dicerna dan dapat dinikmati oleh pemirsa.

Dalam fase ini penulis berkesempatan untuk memberikan sentuhan artistik lebih pada video yang telah di-shoot dan merealisasikan 'dunia doodle' untuk mempresentasikan background visual yang mendukung cerita tersebut. Sketsa environment, elemen grafis, kupu-kupu dan lain-lain dianimasikan dan ditampilkan dalam bentuk goresan tangan. Kemudian Sketsa tersebut diberikan warna yang memberikan informasi tentang keadaan sekitar. Dari titik ini penulis mulai menggabungkan animasi doodle dengan real shot yang telah diambil sebelumnya.

Gambar 11 berikut adalah gambar proses penggabungan dan sekaligus hasil jadinya:
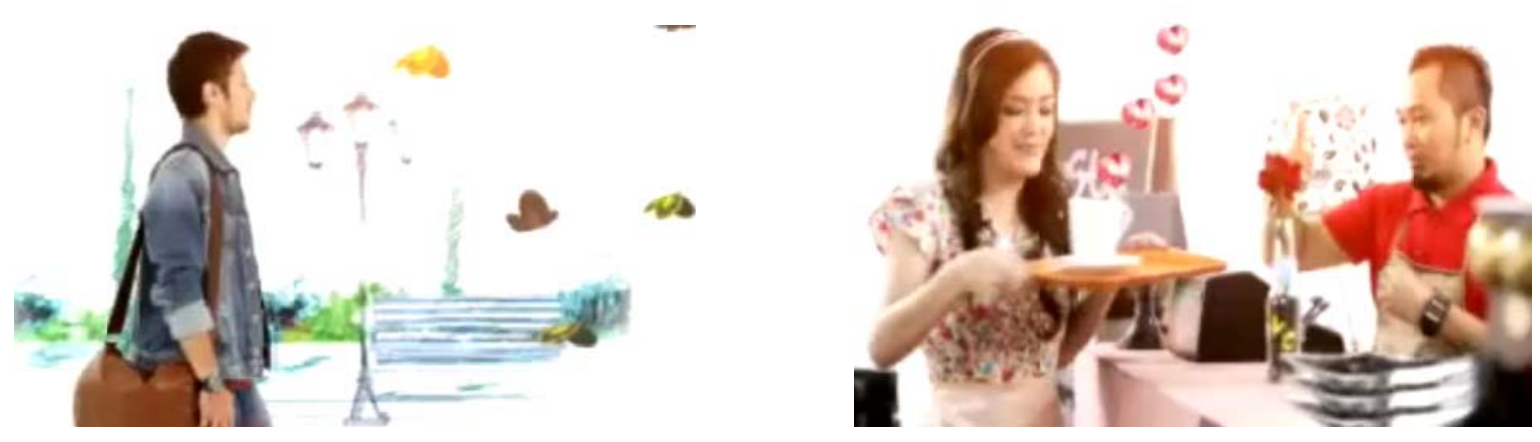

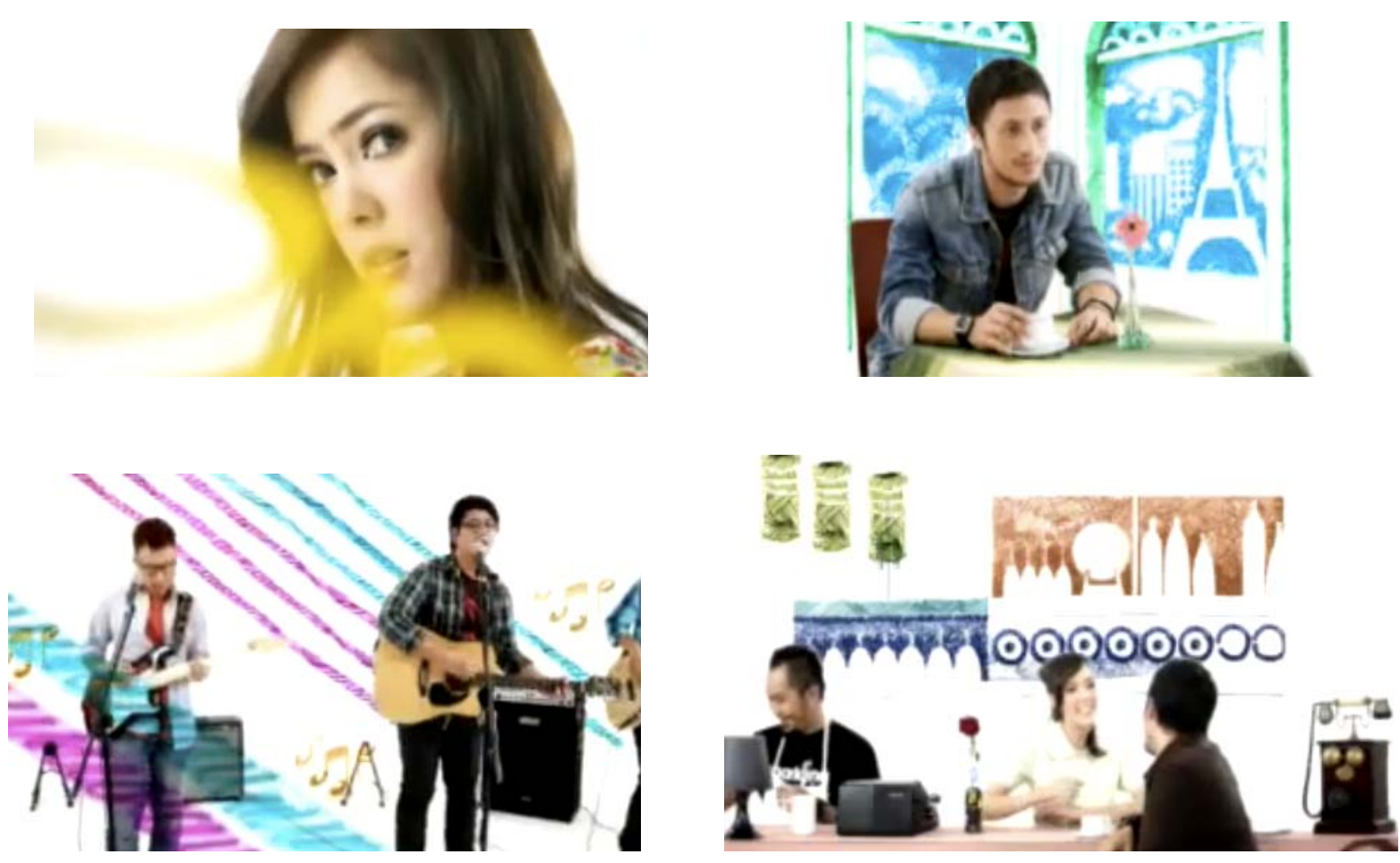

Gambar 11 Gambar yang dipresentasikan menggunakan efek doodle

Gambar 12 menunjukkan ilusi environment dan eksterior café yang menggunakan doodle, sedangkan Gambar 13 menunjukkan transisi dari doodle ke logo.
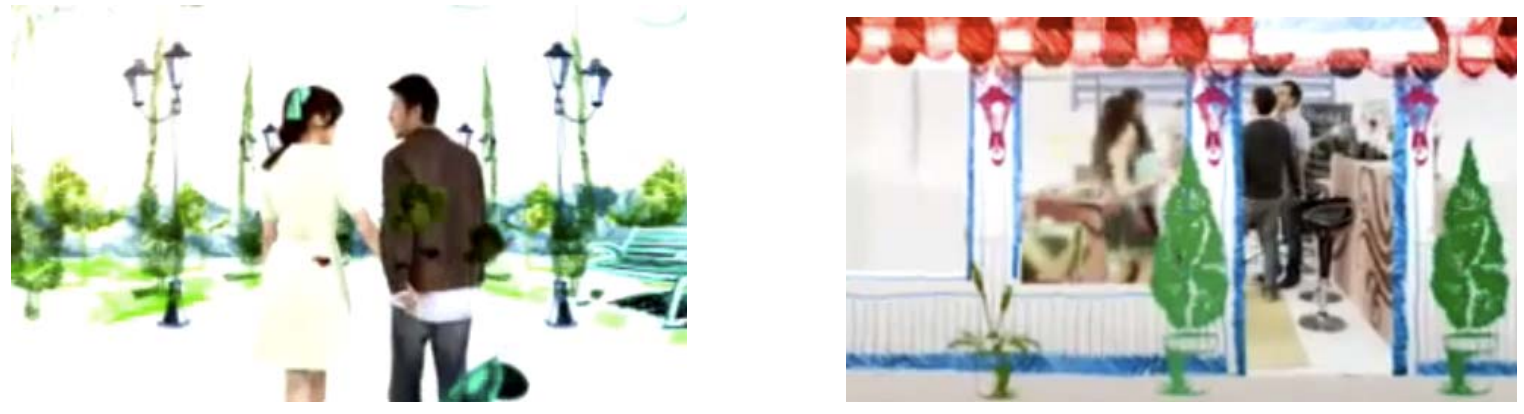

Gambar 12 Gambar ilusi environment dan eksterior café dengan ilusi doodle
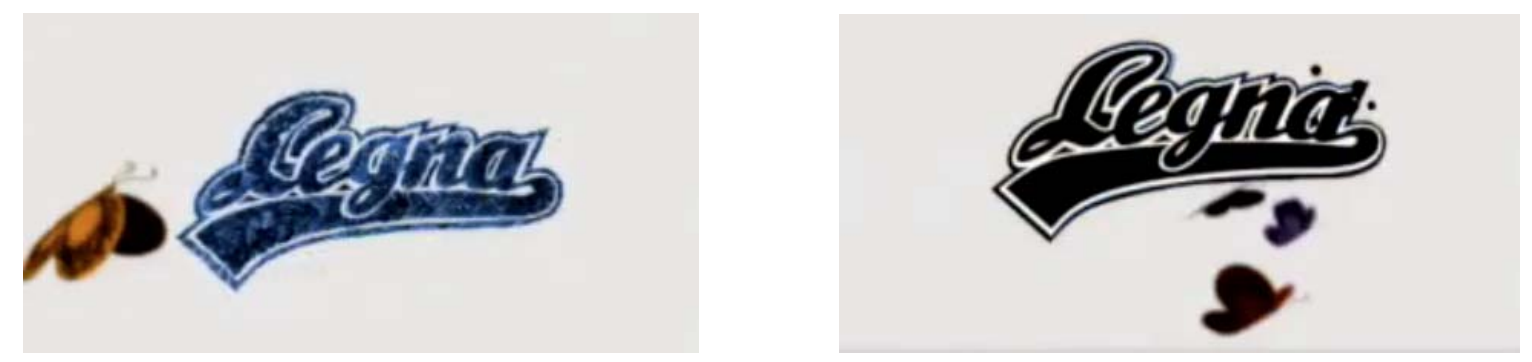

Gambar 13 Gambar transisi dari doodle menuju real logo 


\section{PENUTUP}

Perkembangan dunia animasi tidak berjalan sebagai sebuah hirarki yang linier, dimana ada anggapan bahwa suatu gaya animasi lebih "bagus" daripada gaya yang lain, tanpa bisa menguraikan subjektifitas "bagus" itu sendiri. Sebagai sebuah karya visual, animasi dibuat untuk menjadi solusi kreatif, yang artinya tidak mungkin dipukul rata sebagai sebuah format tunggal. Benar bahwa perkembangan teknologi 3D saat ini sangat membantu untuk mewujudkan animasi yang realis, modern.Tetapi tidak semua permasalahan kreatif bisa diselesaikan dengan 3D. Pembuatan video klip Legna tersebut diatas adalah satu contoh bahwa animasi tidak semata-mata tentang teknik, bukan hanya soal dikotomi 2D-3D, juga stigma seolah animasi 2D tidak up to date. Bahkan hal yang sepele seperti doodle atau sketsa pensil bisa dijadikan satu karya animasi yang menarik. Sebuah video klip bisa diselesaikan secara efisien dengan budget dan resource yang terbatas.Hal ini juga untuk mengingatkan kembali bahwa senjata utama seorang kreatif bukanlah pada alat yang digunakan, tetapi kreatifitas itu sendiri.

\section{DAFTAR PUSTAKA}

Duggan, J. M., (2008). The Doodle Book: 187 Fun Drawings You Can Finish Yourself. Berkeley: Ulysses Press.

Duggan, J. M., (2008). The Action-Packed Book Of Adventure Doodles: 160 Fun And Exciting Drawings You Can Finish Yourself. Berkeley: Ulysses Press.

Coupe, P. (2010). Doodle Maniacs: How Do You Doodle?. London: Arcturus Publishing Ltd. 